2014s-31

\title{
Global Value Chains and Trade Elasticities
}

\author{
Byron S. Gangnes, Alyson C. Ma, Ari Van Assche
}

Série Scientifique
Scientific Series

\section{Montréal \\ Juin 2014}

(C) 2014 Byron S. Gangnes, Alyson C. Ma, Ari Van Assche.. Tous droits réservés. All rights reserved.

Reproduction partielle permise avec citation du document source, incluant la notice $($ )

Short sections may be quoted without explicit permission, if full credit, including (C) notice, is given to the source.
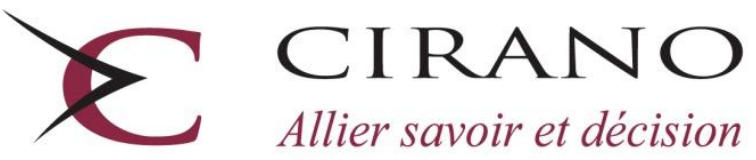

Allier savoir et décision

Centre interuniversitaire de recherche en analyse des organisations 


\section{CIRANO}

Le CIRANO est un organisme sans but lucratif constitué en vertu de la Loi des compagnies du Québec. Le financement de son infrastructure et de ses activités de recherche provient des cotisations de ses organisations-membres, d'une subvention d'infrastructure du Ministère de l'Enseignement supérieur, de la Recherche, de la Science et de la Technologie, de même que des subventions et mandats obtenus par ses équipes de recherche.

CIRANO is a private non-profit organization incorporated under the Québec Companies Act. Its infrastructure and research activities are funded through fees paid by member organizations, an infrastructure grant from the Ministère de l'Enseignement supérieur, de la Recherche, de la Science et de la Technologie, and grants and research mandates obtained by its research teams.

\section{Les partenaires du CIRANO}

\section{Partenaire majeur}

Ministère de l'Enseignement supérieur, de la Recherche, de la Science et de la Technologie

\section{Partenaires corporatifs}

Autorité des marchés financiers

Banque de développement du Canada

Banque du Canada

Banque Laurentienne du Canada

Banque Nationale du Canada

Banque Scotia

Bell Canada

BMO Groupe financier

Caisse de dépôt et placement du Québec

Fédération des caisses Desjardins du Québec

Financière Sun Life, Québec

Gaz Métro

Hydro-Québec

Industrie Canada

Intact

Investissements PSP

Ministère des Finances et de l'Économie

Power Corporation du Canada

Rio Tinto Alcan

Transat A.T.

Ville de Montréal

\section{Partenaires universitaires}

École Polytechnique de Montréal

École de technologie supérieure (ÉTS)

HEC Montréal

Institut national de la recherche scientifique (INRS)

McGill University

Université Concordia

Université de Montréal

Université de Sherbrooke

Université du Québec

Université du Québec à Montréal

Université Laval

Le CIRANO collabore avec de nombreux centres et chaires de recherche universitaires dont on peut consulter la liste sur son site web.

Les cahiers de la série scientifique (CS) visent à rendre accessibles des résultats de recherche effectuée au CIRANO afin de susciter échanges et commentaires. Ces cahiers sont écrits dans le style des publications scientifiques. Les idées et les opinions émises sont sous l'unique responsabilité des auteurs et ne représentent pas nécessairement les positions du CIRANO ou de ses partenaires.

This paper presents research carried out at CIRANO and aims at encouraging discussion and comment. The observations and viewpoints expressed are the sole responsibility of the authors. They do not necessarily represent positions of CIRANO or its partners. 


\title{
Global Value Chains and Trade Elasticities
}

\author{
Byron S. Gangnes * Alyson C. Ma ${ }^{*}$, Ari Van Assche $e^{*}$
}

\section{Résumé/abstract}

Previous studies have argued that global value chains (GVCs) have increased the sensitivity of trade to foreign income shocks. This may occur either because GVC trade is concentrated in durable goods industries, which are known to have high income elasticities (a composition effect), or because, within industries, GVC trade has a higher income elasticity than regular trade (a supply chain effect). Using Chinese trade data across customs regimes and industries during the period 1995-2009, we find evidence for the former, but not the latter.

Mots clés/Key words:: global value chains, trade elasticities, supply chain effect, composition effect

\footnotetext{
${ }^{*}$ University of Hawaii at Manoa.

University of San Diego.

ॠHEC Montréal, Department of International Business, 3000 Chemin de la Côte-Sainte-Catherine, Montréal (Québec), Canada H3T-2A7. Phone: (514)340-6043. Fax: (514)340-6987. E-mail: ari.van-assche@ hec.ca
} 


\section{Introduction}

Can the emergence of global value chains (GVCs) explain the documented rise in the income elasticity of global trade (Cheung and Guichard 2009, Freund 2009)? Recent studies have highlighted two possible channels through which this may have occurred. Bems et al. (2010) and Eaton et al. (2010) suggest that GVCs have primarily emerged in durable goods sectors, therefore altering the composition of trade. Since durables have higher income elasticities, this has made aggregate trade more sensitive to foreign income shocks (a composition effect).

By contrast, Alessandria et al. (2010) argue that characteristics inherent to the structure of global supply chains may cause income elasticities in GVC trade to be higher than for regular trade (a supply chain effect). GVCs, for example, require firms to hold disproportionately large inventories of imported inputs. During economic downturns, firms draw down these inventories to maintain production while suspending new purchases of imported inputs. The disproportionate falloff in upstream imports within GVCs can lead to a heightened sensitivity of trade to foreign income shocks.

The relative importance of these two channels remains an unsettled matter (Altomonte and Ottaviano, 2009). Decomposing these effects requires data that distinguish between GVC trade and regular trade, which are difficult to come by. In this paper, we address the issue by exploiting a dataset covering China's trade by customs regime. Using a variant of the workhorse export-demand model, we evaluate the existence of a composition effect and supply chain effect in Chinese exports.

\section{Processing versus ordinary trade}

Our focus on Chinese trade is pertinent for two reasons. First, similar to aggregate trade, the income elasticity of Chinese exports has risen significantly in the past decades (Aziz and Li, 2008). Second, trade data from China's Customs Statistics allow us to distinguish between trade under the processing trade $(\mathrm{PT})$ regime and ordinary trade (OT) regime. Under PT, firms enjoy duty-free importation of inputs that are used in production, but face restrictions on selling to the domestic market. As a result, firms use it almost exclusively if they rely heavily on imported inputs and export their products, i.e. if they are part of GVCs. Under OT, firms face duties on imported inputs but can sell their output locally. Firms that export under the OT regime, therefore, have more extensive domestic value chains. Two stylized facts back this up. First, processing exports embody less than half as much domestic value-added as ordinary exports (Koopman et al., 2012). 
Second, in 2009, foreign-invested enterprises dominated PT with an exports share of $84 \%$, while Chinese firms dominated OT with an exports share over $70 \%$.

GVC trade has gained importance in China's exports. As shown in Table 1, the share of processing exports has increased from $38 \%$ in 1995 to $51 \%$ in 2009 . These processing exports are concentrated in rapidly growing durable goods sectors. In 2009, PT accounted for $64 \%$ of durable goods exports, but only $27 \%$ of non-durable goods exports. As a consequence, the composition of Chinese exports has shifted both to durable goods and GVC trade. Disentangling these two phenomena may help us understand the evolution of China's trade elasticities.

\section{[Table 1]}

Our paper is related to recent studies that investigate the role of PT on the stability of China's trade elasticities. Cheung et al. (2012) and Thorbecke and Smith (2010) find that aggregate processing exports have a higher income elasticity than aggregate ordinary exports. Both studies acknowledge that this result may be because processing exports contain more capital-intensive goods, which may have higher income elasticities. Our contribution is to specifically assess this possibility by investigating whether PT has a higher income elasticity than OT once we control for composition effects.

\section{Data and methods}

To estimate China's trade elasticities, we build on the workhorse export-demand model, which relates the demand for exports to foreign income and relative prices (Goldstein and Kahn 1985). We modify the model by adding a supply-side variable to take into account the effect of rapid productivity improvements in China (Chinn, 2010):

$$
\Delta \ln x_{r k t}=\alpha+f e_{r k}+\beta \Delta \ln r g d p_{r k t}+\gamma \Delta \operatorname{lnrer}_{t}+\delta \Delta \ln \sup _{t}+\varepsilon_{r k t}
$$

Here $x_{r k t}$ is real exports under regime $r$ in industry $k$ and at time $t ; f e_{r k}$ are industryregime fixed effects; $r g d p_{r k t}$ is real foreign income under regime $r$ in industry $k$ and at time $t ; \operatorname{rer}_{t}$ is the Chinese real exchange rate; and $s u p_{t}$ is a supply-side variable. To avoid spurious results due to non-stationary regressors, we estimate the equation in differenced logarithms (approximately growth rates). ${ }^{1}$

\footnotetext{
${ }^{1}$ An alternative approach is to estimate the model in a cointegration framework. In a panel setting, however, estimation of cointegrating relationships is complicated by heteroskedasticity and potential crosssectional dependence (Bai et al., 2009). In our case, the very short available time series makes evaluation and treatment of these issues difficult.
} 
For the dependent variable, we use Chinese annual exports to OECD countries, disaggregated by the twelve sectors identified in Table 1 and by customs regime. We deflate exports using industry-level Hong Kong re-export unit value indexes.

For our foreign income measure, we use the export-weighted real GDP of the OECD countries, where weights equal the share of Chinese exports in industry $k$ and regime $r$ destined for each country. We obtained the real GDP data from the IMF's International Financial Statistics.

Due to the poor coverage of export prices for China, we use the IMF's CPI deflated trade-weighted index of the RMB against a broad basket of currencies as a measure for $\operatorname{rer}_{t}$.

Finally, for our supply-side variable, we use China's total factor productivity (TFP) growth, obtained from the Conference Board's Total Economy Database.

To investigate variations in trade elasticities across sectors and regimes, we estimate the following encompassing export-demand equation:

$$
\begin{aligned}
& \Delta \ln x_{r k t}=\alpha+f e_{r k}+\beta_{1} \Delta \operatorname{lnrgdp_{rkt}}+\beta_{2} \Delta \operatorname{lnrgdp_{rkt}} * d u r_{k}+ \\
& \beta_{3} \Delta \operatorname{lnrgdp} p_{r k t} * \operatorname{proc}_{r}+\beta_{4} \Delta \operatorname{lnrgdp} p_{k t} * d u r_{k} * \operatorname{proc}_{r}+\gamma_{1} \Delta \operatorname{lnrer}_{t}+ \\
& \gamma_{2} \Delta \text { lnrer }_{t} * d u r+\gamma_{3} \Delta \text { lnrer }_{t} * \text { proc }_{r}+\gamma_{4} \Delta \text { lnrer }_{t} * d u r_{k} * \operatorname{proc}_{r}+\delta \Delta \ln \sup _{t}+\varepsilon_{r k t}
\end{aligned}
$$

$d u r_{k}$ is a dummy that equals 1 for durables, and 0 otherwise; $p r o c_{r}$ is a dummy that equals 1 if trade occurs under PT, and 0 otherwise. To distinguish between durables and non-durables, we follow Engel and Wang (2011) (see Table 1).

There will be evidence of a composition effect if $\beta_{2}>0$. In that case, the income elasticity of exports is higher for durables than for non-durables. There will be evidence of a supply chain effect if $\beta_{3}>0$ or $\beta_{4}>0$. This would indicate that, within industries, the income elasticity of processing exports is larger than for ordinary exports.

\section{Results}

We present our results in Table 2. All regressions are estimated with a single lag of each independent variable to allow for the possibility of gradual adjustment of exports to income and exchange rate movements and to eliminate first-order serial correlation from regression residuals. In all equations, we compute standard errors that are robust to heteroscedasticity and autocorrelation within panels.

\section{[Table 2]}


Columns 1 and 2 present our estimates for equation (1), where the analysis is disaggregated at the industry level. Overall, the equation appears to reasonably describe Chinese exports, with estimates that are within the range of previous studies (e.g. Cheung et al., 2012). The income elasticity is positive and significant with an impact effect of 1.5 when $\Delta l n t f p_{t}$ is excluded and 1.8 when it is included. The price elasticity is negative and significant, with a cumulative effect of contemporaneous and one-period-lagged values of 1.3 to 1.4 . TFP growth exerts only a small effect on exports, presumably because the industry fixed effects capture much of the trend growth in exports.

The column 3 regression augments equation (1) with interaction dummies for durable goods. In line with the composition effect - and consistent with previous studies - durable goods exports are much more sensitive to foreign income shocks than non-durables. The coefficient on $\Delta \ln R G D P * d u r$ is positive and significant, and its magnitude indicates that the income elasticity of durable goods is nearly four times as large as that of nondurables. There is no evidence that durable goods exports have a different price elasticity than non-durables.

Column 4 reports our estimate of equation (2), where exports are further disaggregated into PT and OT. The effect of durability is similar to that in column 3. However, the

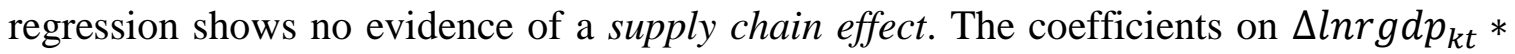

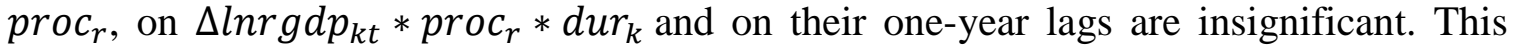
suggests that, within sectors, processing exports do not have statistically different income elasticities than ordinary exports. There is also no evidence that processing exports have different price responsiveness than non-processing exports.

Table 1 reveals that much of the compositional change in Chinese exports has taken place in three industries: machinery, textiles, and non-manufactures. To test whether these three industries may be driving the results, column 5 reports a regression where they are omitted. The results are robust to the exclusion of these industries.

Our central results are robust to alternative specifications. They are unaffected by the inclusion of a lagged dependent variable, year fixed effects, or the exclusion of lagged independent variables. Similarly, the results are invariant to two alternative supply side variables: China's relative productivity, measured by China's real GDP per capita relative to the U.S. output per man-hour or China's fixed asset investment to GDP ratio. Finally, as we show in the appendix table, they are unaffected by the use of the BLS price index for U.S. imports from non-industrial countries as an alternative export price deflator. 


\section{Conclusion}

This paper empirically investigates the differences in trade elasticities across Chinese industries and customs regimes. We find evidence that durable exports are four times more sensitive to foreign income shocks than nondurables. We find no evidence, however, that within industries processing exports have a higher income elasticity than ordinary exports. These results suggest that if China's growing integration in GVCs has affected the income elasticity of its exports, it is through a composition effect, and not through a supply chain effect.

A potential reason for the lack of a supply chain effect may be that they occur only under certain circumstances. Chen and Lee (2009), for example, suggest that the size of bullwhip effects in supply chains is affected by the degree of demand uncertainty. This may explain the detection of supply chain effects during the Great Recession of 20082009 (Alessandria et al. 2010), but not in our longer-term data analysis. More research is needed to investigate the conditions under which supply chain effects influence aggregate trade elasticities. 


\section{Bibliography}

Alessandria G., Kaboski, J., Midrigan, V., 2010. The great trade collapse of 2008-2009: an inventory adjustment? IMF Economic Review 58: 254-294.

Altomonte, C., Ottaviano, G., 2009. Resilient to the crisis? Global supply chains and trade flows. Vox, November 27.

Aziz, J., Li., C., 2008. China's changing trade elasticities. China \& World Economy 16: $1-21$.

Bai, J, Kao, C., Ng, S., 2009. Panel cointegration with global stochastic trends. Journal of Econometrics 149: 82-99.

Bems, R., Johnson, S., Yi, K.-M., 2010. Demand spillovers and the collapse of trade in the global recession. IMF Economic Review 58: 295-326.

Chen, L., H. Lee. Information sharing and order variability control under a generalized demand model. Management Science 55: 781-797.

Cheung, Y.-W., Chinn, M., Qian, X., 2012. Are Chinese trade flows different? Journal of International Money and Finance 31: 2127-2146.

Cheung, C., Guichard, S., 2009. Understanding the world trade collapse. OECD Working Paper 729.

Chinn, M., 2010, Supply capacity, vertical specialization and trade costs: the implications for aggregate U.S. trade flow equations, mimeo.

Eaton, J., Kortum, S., Neiman, B., Romalis, J., 2011. Trade and the global recession. NBER Working Paper 16666.

Engel, C., Wang, J. 2011. International trade in durable goods: Understanding volatility, cyclicality, and elasticities. Journal of International Economics 83: 37-52.

Freund, C. 2009. The trade response to global downturns: historical evidence. World Bank Policy Research Working Paper 5015.

Goldstein, M., Khan, M., 1985. Income and price effects in foreign trade. In Jones, R., Kenen P. (eds.) Handbook of International Economics Vol. 2 (Amsterdam: Elsevier).

Koopman, R., Wang, Z., Wei, S.-J., 2012. Estimating domestic content in exports when processing trade is pervasive. Journal of Development Economics 99:178-189.

Thorbecke, W., Smith, G., 2010. How would an appreciation of the Renminbi and other East Asian currencies affect China's exports? Review of International Economics 18: 95108. 
Table 1: China's exports, by sector, various years

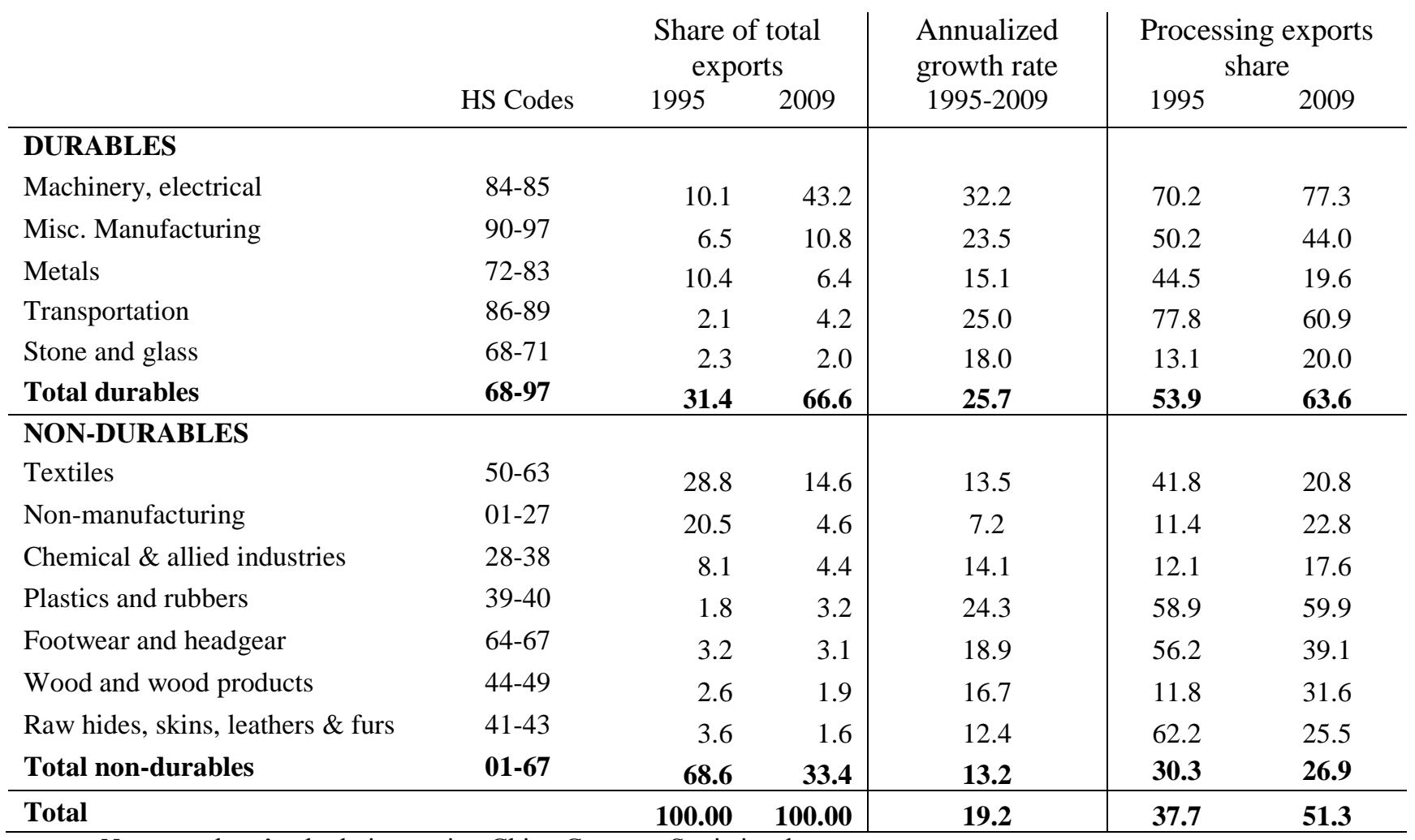

Notes: authors' calculations using China Customs Statistics data 
Table 2: Regression Results, 1995-2009

\begin{tabular}{|c|c|c|c|c|c|}
\hline \multirow[t]{2}{*}{ Dependent variable } & \multicolumn{5}{|c|}{ Real exports growth } \\
\hline & (1) & (2) & (3) & (4) & (5) \\
\hline \multirow[t]{2}{*}{$\Delta \operatorname{lnRGDP}$} & $1.503 * * *$ & $1.831 * * *$ & $1.123 * * *$ & $1.072^{* *}$ & $1.356^{* *}$ \\
\hline & {$[0.524]$} & {$[0.504]$} & [0.397] & {$[0.416]$} & {$[0.615]$} \\
\hline \multirow[t]{2}{*}{$\Delta \operatorname{lnRGDP}(1-\mathrm{lag})$} & 0.520 & 0.198 & 0.464 & 0.310 & 0.765 \\
\hline & [0.787] & {$[0.686]$} & {$[0.599]$} & {$[0.586]$} & {$[0.810]$} \\
\hline \multirow[t]{2}{*}{$\Delta \operatorname{lnRGDP} *$ durable } & & & $3.052^{* *}$ & $3.608 * *$ & $3.652 * *$ \\
\hline & & & {$[1.306]$} & {$[1.431]$} & {$[1.506]$} \\
\hline \multirow[t]{2}{*}{$\Delta \operatorname{lnRGDP*durable~(1-lag)~}$} & & & -1.007 & -0.875 & -0.777 \\
\hline & & & {$[2.920]$} & {$[2.582]$} & {$[2.733]$} \\
\hline \multirow[t]{2}{*}{$\Delta \operatorname{lnRGDP*}$ processing } & & & & 0.096 & 0.992 \\
\hline & & & & {$[0.563]$} & [0.979] \\
\hline \multirow[t]{2}{*}{$\Delta \operatorname{lnRGDP*}$ processing (1-lag) } & & & & 0.172 & -0.217 \\
\hline & & & & {$[0.841]$} & {$[1.513]$} \\
\hline \multirow[t]{2}{*}{$\triangle \operatorname{lnRER}$} & $-0.996 * *$ & -0.315 & 0.232 & 0.561 & 0.668 \\
\hline & {$[0.488]$} & {$[0.541]$} & {$[0.417]$} & {$[0.366]$} & {$[0.437]$} \\
\hline \multirow[t]{2}{*}{$\Delta \operatorname{lnRER}(1-\operatorname{lag})$} & -0.338 & $-1.080 * *$ & $-1.266 * * *$ & $-1.588 * * *$ & $-1.275 * * *$ \\
\hline & [0.364] & {$[0.476]$} & [0.417] & {$[0.391]$} & {$[0.461]$} \\
\hline \multirow[t]{2}{*}{$\Delta \operatorname{lnRER} *$ durable } & & & -0.910 & -0.848 & -0.790 \\
\hline & & & [1.089] & [0.946] & {$[0.995]$} \\
\hline \multirow[t]{2}{*}{$\Delta \operatorname{lnRER} *$ durable (1-lag) } & & & 0.499 & 0.332 & 0.313 \\
\hline & & & {$[0.763]$} & {$[0.716]$} & {$[0.741]$} \\
\hline \multirow[t]{2}{*}{$\Delta \operatorname{lnRER} *$ processing } & & & & -1.021 & -0.947 \\
\hline & & & & {$[0.632]$} & {$[0.766]$} \\
\hline \multirow[t]{2}{*}{$\Delta \operatorname{lnRER} *$ processing (1-lag) } & & & & 0.680 & 0.591 \\
\hline & & & & {$[0.443]$} & {$[0.578]$} \\
\hline \multirow[t]{2}{*}{$\Delta \operatorname{lnRGDP} *$ processing*durable } & & & & -1.512 & -2.578 \\
\hline & & & & [1.859] & [2.032] \\
\hline \multirow[t]{2}{*}{$\Delta \operatorname{lnRGDP} *$ processing*durable (1-lag) } & & & & -0.466 & 0.278 \\
\hline & & & & {$[4.460]$} & [4.724] \\
\hline \multirow[t]{2}{*}{$\Delta \operatorname{lnRER} *$ processing*durable } & & & & -0.463 & -0.479 \\
\hline & & & & {$[1.631]$} & [1.696] \\
\hline \multirow[t]{2}{*}{$\Delta \operatorname{lnRER} *$ processing*durable (1-lag) } & & & & 0.417 & 0.475 \\
\hline & & & & {$[1.202]$} & {$[1.261]$} \\
\hline \multirow[t]{2}{*}{$\Delta \operatorname{lnTFP}$} & & $0.014 * *$ & $0.016^{* *}$ & $0.014 * *$ & $0.017 * * *$ \\
\hline & & {$[0.007]$} & {$[0.007]$} & {$[0.005]$} & {$[0.007]$} \\
\hline \multirow[t]{2}{*}{$\Delta \operatorname{lnTFP}(1-\operatorname{lag})$} & & $-0.021 * * *$ & $-0.021 * * *$ & $-0.022 * * *$ & $-0.021 * * *$ \\
\hline & & {$[0.006]$} & {$[0.005]$} & {$[0.004]$} & {$[0.005]$} \\
\hline Industry fixed effects & Yes & Yes & Yes & No & No \\
\hline Industry-regime fixed effects & No & No & No & Yes & Yes \\
\hline R-squared & 0.259 & 0.315 & 0.364 & 0.348 & 0.342 \\
\hline Observations & 156 & 156 & 156 & 312 & 260 \\
\hline
\end{tabular}

Notes: In columns (1)-(3), the analysis is conducted at the industry level. In columns (4)-(5), the analysis is disaggregated to the industry-regime level. A constant term is included in all specifications but is not reported here. Standard errors are reported in brackets and are robust to heteroscedasticity and autocorrelation within panels. *indicates significant at $10 \%$; **significant at 5\%; ***significant at $1 \%$. 


\section{Appendix Table: Regression Results with BLS price deflator, 1995-2009}

\begin{tabular}{|c|c|c|c|c|c|}
\hline \multirow[t]{2}{*}{ Dependent variable } & \multicolumn{5}{|c|}{ Real exports growth } \\
\hline & (1) & (2) & (3) & (4) & (5) \\
\hline \multirow[t]{2}{*}{$\Delta \ln R G D P$} & $1.044 * *$ & $1.391 * * *$ & $0.758 * *$ & $0.709 *$ & $1.006^{*}$ \\
\hline & [0.423] & {$[0.405]$} & {$[0.362]$} & {$[0.372]$} & {$[0.563]$} \\
\hline \multirow[t]{2}{*}{$\Delta \operatorname{lnRGDP}(1-\mathrm{lag})$} & 0.360 & 0.281 & 0.312 & 0.211 & 0.452 \\
\hline & {$[0.395]$} & [0.395] & {$[0.400]$} & {$[0.423]$} & {$[0.740]$} \\
\hline \multirow[t]{2}{*}{$\Delta \operatorname{lnRGDP} *$ durable } & & & $2.616^{* * *}$ & $3.404 * * *$ & $3.130 * * *$ \\
\hline & & & {$[0.945]$} & {$[1.006]$} & [1.118] \\
\hline \multirow[t]{2}{*}{$\Delta \operatorname{lnRGDP*durable~(1-lag)~}$} & & & 0.172 & 0.282 & 0.592 \\
\hline & & & [1.333] & {$[1.256]$} & {$[1.374]$} \\
\hline \multirow[t]{2}{*}{$\Delta \operatorname{lnRGDP*}$ processing } & & & & -0.260 & 1.088 \\
\hline & & & & {$[0.518]$} & {$[0.864]$} \\
\hline \multirow[t]{2}{*}{$\Delta \operatorname{lnRGDP*}$ processing (1-lag) } & & & & 0.229 & -0.153 \\
\hline & & & & {$[0.596]$} & [1.335] \\
\hline \multirow[t]{2}{*}{$\triangle \ln R E R$} & -0.496 & 0.097 & 0.266 & 0.603 & 0.632 \\
\hline & {$[0.315]$} & {$[0.362]$} & {$[0.374]$} & {$[0.352]$} & {$[0.444]$} \\
\hline \multirow[t]{2}{*}{$\Delta \operatorname{lnRER}(1-\operatorname{lag})$} & $-1.176^{* * *}$ & $-1.531 * * *$ & $-1.451 * * *$ & $-1.748 * * *$ & $-1.510 * * *$ \\
\hline & {$[0.290]$} & {$[0.327]$} & {$[0.350]$} & {$[0.356]$} & {$[0.448]$} \\
\hline \multirow[t]{2}{*}{$\Delta \operatorname{lnRER} *$ durable } & & & -0.091 & 0.024 & 0.113 \\
\hline & & & {$[0.676]$} & [0.606] & [0.690] \\
\hline \multirow[t]{2}{*}{$\Delta \operatorname{lnRER} *$ durable (1-lag) } & & & 0.035 & -0.143 & -0.220 \\
\hline & & & {$[0.661]$} & {$[0.720]$} & {$[0.757]$} \\
\hline \multirow[t]{2}{*}{$\Delta \operatorname{lnRER} *$ processing } & & & & -0.948 & -0.981 \\
\hline & & & & {$[0.580]$} & [0.763] \\
\hline \multirow[t]{2}{*}{$\Delta \operatorname{lnRER} *$ processing (1-lag) } & & & & 0.684 & 0.636 \\
\hline & & & & [0.446] & {$[0.625]$} \\
\hline \multirow[t]{2}{*}{$\Delta \operatorname{lnRGDP*\text {processing*durable}}$} & & & & -1.849 & $-2.689^{*}$ \\
\hline & & & & [1.400] & [1.583] \\
\hline \multirow[t]{2}{*}{$\Delta \operatorname{lnRGDP} *$ processing*durable (1-lag) } & & & & 0.252 & 0.521 \\
\hline & & & & [2.307] & {$[2.480]$} \\
\hline \multirow[t]{2}{*}{$\Delta \operatorname{lnRER} *$ processing*durable } & & & & -0.520 & -0.431 \\
\hline & & & & {$[1.130]$} & {$[1.217]$} \\
\hline \multirow[t]{2}{*}{$\Delta \operatorname{lnRER} *$ processing*durable (1-lag) } & & & & 0.599 & 0.516 \\
\hline & & & & {$[1.141]$} & [1.186] \\
\hline \multirow[t]{2}{*}{$\Delta \operatorname{lnTFP}$} & & $0.015 * * *$ & $0.016 * * *$ & $0.015 * * *$ & $0.016 * * *$ \\
\hline & & {$[0.005]$} & {$[0.004]$} & {$[0.003]$} & {$[0.004]$} \\
\hline \multirow[t]{2}{*}{$\Delta \operatorname{lnTFP}(1-\operatorname{lag})$} & & $-0.015^{* * *}$ & $-0.014 * * *$ & $-0.015^{* * *}$ & $-0.014 * * *$ \\
\hline & & {$[0.004]$} & {$[0.004]$} & {$[0.004]$} & {$[0.004]$} \\
\hline Industry fixed effects & Yes & Yes & Yes & No & No \\
\hline Industry-regime fixed effects & No & No & No & Yes & Yes \\
\hline R-squared & 0.394 & 0.445 & 0.488 & 0.452 & 0.430 \\
\hline Observations & 156 & 156 & 156 & 312 & 260 \\
\hline
\end{tabular}

Notes: In columns (1)-(3), the analysis is conducted at the industry level. In columns (4)-(5), the analysis is disaggregated to the industry-regime level. A constant term is included in all specifications but is not reported here. Standard errors are reported in brackets and are robust to heteroscedasticity and autocorrelation within panels. *indicates significant at $10 \%$; **significant at $5 \%$; ***significant at $1 \%$. 